
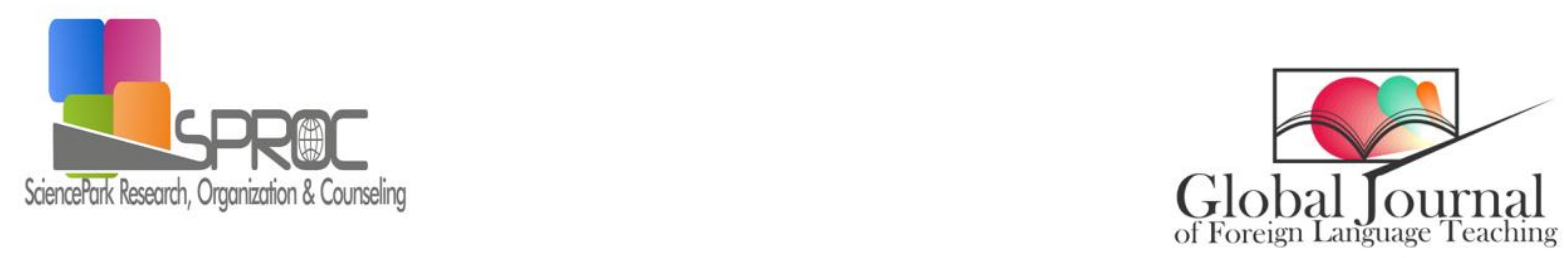

www.gjflt.eu

\title{
Developing intonation skills in English: A systemic functional linguistics perspective
}

\author{
Renata Fabiana Cardinali
}

Maria Celina Barbeito

Suggested Citation:

Global Journal of Foreign Language Teaching. 8

()

Abstract

improvement in students' oral production such as in tone system considering the three systems of intonation in SFL aftera 


\section{Introduction}

even been labelled 'the orphan of second language research and teaching' (Derwing, 2010, p. 24).

These authors suggest that an overemphasis on segmental pronunciation can distract a learner's

speakers' choice of the English tone system may lead to pragmatic incompatibility in the expression of pragmatic approach to intonation proposed by Brazil (1997) to study students' 
proposals for the assessment of students' production in a phonetics and phonology course for first

(Valenzuela Farias, 2013). Some researchers have studied students' perfor

ing students'

(SFL) framework. In a study carried out in 2012, the results show that students' ability to identify

proposed by Allen in 1971, which include directing students' attention to major selected patterns, considering the speaker's intention (Yamato, 2004). This list was extended by Celce

\section{Theoretical framework}


tonality

tone system tonicity

(1)

communicative functions, whilst secondary tones, have a role in expressing speaker's attitudes

\section{Methodology}

3.1. Participants

3.2. Materials 
participants' perceptions of the aspects of phonetics they find difficult to learn. The perception section at aim to assess students' perception of the functions of intonation and their ability to

\subsection{Procedures}

For the research reported here, the focus will be on students' oral production; however, 
The scale is organised in such a way that students' oral performance is assessed in general terms as

Students' production of segmental sounds is recorded and graded in a different section of the is study, two experienced raters listened individually to students' recordings of their reading compared their assessments of students' production and reached agr

\section{Results and discussion}

The analysis of students' responses to the questions about register variables of field, tenor and

\subsection{Was there improvement in students' overall performance after treatment?}

The answer to this question is related to students' overall oral performance which includes an analysis of the data showed that students' remained the same in $25 \%$ (Table 2). The observations made by the raters with regard to students' 
Table 2. Students' overall oral performance during pre

test and student's level of English upon entry into the

Table 3. Students' overall performance and language level

$\longrightarrow$

M

$$
t(-5.745)=0.000,(p
$$

\subsection{Which was the aspect that showed most improvement?}

The analyses of students' performance in relation to the systems of tonality, tonicity and tone show that students' improvement took place in all the systems, but the system that showed most

students' oral performance because after treatment they are more likely to produce a broader range

A comparison of the participants' oral performance with their a 
ined by the fact that during instruction, participants' attention is drawn to

\begin{tabular}{rrr} 
& \multicolumn{3}{c}{-} \\
\hline $8-9$ & $5-7$ & $1-4$ \\
\hline
\end{tabular}

When analysing students' performance during the pre observed that $83 \%$ of the participants get a score of 'poor' and 'fairly good' and that their level of

remain in the bands below 'good'. This may lead us to think that the teaching of the $t$ English may make a difference in students' oral performance even in cases where students may not

\section{Conclusions}

affects the development of students' oral skills, particularly in relation to the systems of tonality,

therefore, further research should be designed towards assessing students' performance in more 


\section{References}

PTLC2009 Proceedings

investigación y extensión

Desafíos de la glotodiversidad en el siglo XXI: ensenanza,

II Jornadas Internacionales de Didactica de la Fonetica de las Lenguas Extranjeras: 31 de agosto y 1 de septiembre de 2012

Acerca de la didactica e investigacion en lenguas extranjeras.

Students oral performance assessment

Teaching pronunciation.

ELT Journal, 51

La pronunciacion del futuro profesor de ingles: una propuesta de evaluacion alternativa de los aprendizajes en Fonetica y Fonologia I (UNMdP). VI Jornadas Nacionales sobre la Formación del Utopian goals for pronunciation teaching.

TESOL QUARTERLY, 39

Language Learning, 48

Applied Language Learning, 13

Fonetica y Fonología. Articulacion entre ensenanza e investigacion 
Second Language Learning and Teaching Conference

An introduction to functional grammar

Intonation in the grammar of English

Halliday's introduction to functional grammar

and applied linguistics challenges for theory and practice

Spoken English, TESOL

la Fonética de las Lenguas Extranjeras -

Genre rela tions: mapping culture

I Jornadas Internacionales de Didáctica de

I Jornadas Internacionales de Didactica de la

Fonetica de las Lenguas Extranjeras

Phonology II students at ISP "Dr. Joaquin V. Gonzalez" teacher training college. In G. Leighton (Ed.), I Jornadas Internacionales de Didactica de la Fonética de las Lenguas Extranjeras

Intercultural Pragmatics, 6

International ICAME Journal, $26 \quad-$

Journal of Pragmatics, 37

I Jornadas Internacionales de Didactica de la Fonetica de las Lenguas Extranjeras

The intonation system of English

RBLA, Belo Horizonte, 13

English intonation an introduction

The music of everyday speech. Prosody and discourse analysis.

Prospect, 19 